\title{
ECOLOGICAL AND SOCIAL IMPACTS OF EUCALYPTUS TREE PLANTATION ON THE ENVIRONMENT
}

\author{
Bayle, G. K. \\ Amhara Agricultural Research Institute (Adet Agricultural Research Centre), Bahir Dar, Ethiopia
}

\begin{abstract}
Eucalyptus is an ever green flowering tree and a shrub which belong to the family Myrtaceae, subfamily Myrotideae and consists of some 800 species. This tree is native to Australia and widely planted for various uses in the different parts of Ethiopia integrating into the various farming systems, and their planting has resulted in high economic profitability. It is over a century since eucalyptus was introduced in Ethiopia for multipurpose use and rescues the remaining indigenous forests from being destroyed, for controlling soil erosion, for replacing indigenous species for fuel-wood, thereby preventing further degradation of natural forests by quickly producing firewood, would eliminate the causes which frequently may have led to land degradation and desertification and also a food and habitat for wild animals. But, it also a harmful effect on the environment, uses a lot of nutrient which is leading to soil exhaustion and reduction of crop yields, secretion of allelochemical and decreasing crop production, but the trees are neither good nor bad, and careful analysis of the ecological and social implications should be undertaken before planting. Decisions, such as what, where, why and how to grow and how to manage it have to be made; and the social and ecological implications of each decision, as well as the economic implications, have to be weighted up.
\end{abstract}

Key words: Eucalyptus; Plantation; Forest; Eucalyptus impact.

\section{INTRODUCTION}

There are high increasing demands for wood for industrial uses and fuel needs, especially in the developing countries of the tropics with their increasing populations. To cope with this situation, people often opt to plant fast growing, highly utilizable, exotic tree species (Zerga 2015). In Ethiopia different species of Eucalyptus are widely planted for various uses (Friis 1995). In the highlands part of Ethiopia, Eucalyptus species are commonly integrated with the various farming systems and their planting has resulted in high economic profitability compared with the agricultural use of land for crop production (Lemenih 2010).

The word eucalyptus comes from the Greek words "Eu" and "Kalypta" with the meaning "Well" and "Cover", respectively and together gives a meaning "well cover". Therefore, the name eucalyptus refers to a small cap covering the closed flower; it is described as ever green flowering tree and shrub concerning the specific habitats (Khan and Mahmood-Ul-Hasan 2006). It is native to Australia and Tasmania with a small number of species also found in New Guinea, the Philippines and Indonesia (Abebe and Tadesse 2003) and has become the most widely planted genus of tree in the world. It covers at least 12 million ha of land throughout the tropical zone, 90\% of which have been established since 1955 (Turnbull 1999). Outside its native habitat, eucalyptus was first grown in Portugal some four hundred years ago. Subsequently, the species became widely distributed in Europe, Latin America, Asia and Africa. Prominent among some of the countries are USA (California), Ecuador, Colombia, Chile, China, Spain, Israel, Ethiopia, Morocco, South Africa and Uganda. In all, over ten million hectare of eucalyptus are found in the tropics at the end of 1990 (Abebe and Tadesse 2003). The genus was introduced to East Africa in the late 19th and early 20th century and by the early 1970s the area of eucalypts in Ethiopia, Rwanda, Uganda, Kenya and Sudan had reached 95,684 ha (FAO 1979). The largest plantations at that time were in Ethiopia and Rwanda, at 42,300 ha and 23000 ha, respectively.

It is over a century since eucalyptus had been introduced in Ethiopia. Emperor Menelik II (18681907) introduced eucalyptus to Ethiopia in 1895 from different countries, mainly from Australia. Its 
seedlings were raised in the palace nursery and planted in the city. To assure its fast dissemination, seeds and seedlings were distributed freely to landowner with tax relief as incentive. Given its adaptation, fast growth and good yield, it has provided fuel wood, construction material, scaffold, transmission pole, timber etc. At present, there is over half million hectare of eucalyptus in the country (Abebe and Tadesse 2003).

Eucalyptus is the most commonly grown tree species in government plantation as well as community programme and household woodlots. This tree species grows well even on poor soil and grows faster compared to most indigenous tree species. Smallholders show a clear preference for Eucalyptus poles, which are useful for farm implements and constructing houses and fences (Muluneh 2011). In addition, the sale of Eucalyptus poles and products has the potential to raise farm incomes, reduce poverty, increase food security and diversify smallholder farming systems in many areas of Amhara region (Zerfu 2002) and plays a great role as a main source of fuel wood for both urban and rural inhabitants.

Eucalyptus was introduced with the purpose of providing multipurpose use and rescues the remaining indigenous forests from being destroyed. It has high socio-economic and ecological benefits to the world. Many plantations of Eucalyptus species have been found to host high herbaceous species richness and foster natural regeneration of woody species, such as Juniperus procera, Podocarpus falcatus, etc. as can be seen at Entoto and elsewhere in Ethiopia. Eucalyptus plantation can have a catalytic effect on regeneration of native species and used as a management tool for restoration of degraded forest lands (Gil et al. 2010).

Eucalyptus gives superior and versatile benefits compared to many other tree species due to the fact that farmers often choose to plant eucalyptus, particularly smallholders in tropical and subtropical regions (Hailemicael 2012).

But, it has also a harmful effect on the environment and ecology by draining water resources; it enhances soil erosion, suppresses undergrowth, depletes soil nutrients and allopathically affects nearby agricultural crop. Even though, there has been concern among users, growers, stakeholders, scientists and farmers that Eucalyptus trees are affecting ecosystem both negatively and positively. The environmental impacts and ecological services of Eucalyptus trees have been studied only to limited extent. Therefore, the main objective of this review paper is to highlight the socio-economic and environmental impacts of Eucalyptus.

\section{THE TEXT}

A critical review was carried out of following 23 scientific journal articles, six case studies, three books and 16 other publications (viz. governmental reports, conference proceedings and book chapters). This review was further illustrated through participatory field observation.

\section{Positive impacts of Eucalyptus on the environment}

The greatest positive contribution of eucalyptus is perhaps replacing indigenous species for fuelwood, thereby preventing further degradation of natural forests. Furthermore, certain Eucalyptus species, by quickly producing firewood, would eliminate the causes which frequently may have led to land degradation and desertification (Kenya forest service 2009).

Planting eucalyptus has a persistent effect on the land use of both temperate and tropical areas by affecting the microclimate condition, decreasing soil fertility, attracting seed dispersers and depressing competitive grasses (Lemineh and Teketay 2005). Plantation is an alternative site for the regeneration of native plant species (Senbeta et al. 2002). The tree plantations enhance the regeneration by suppressing competitive grass species, and other light demanding species and creating a micro-climate that favors colonization and as "stepping stones" between remnant natural forests and agricultural matrix enhancing seed dispersal. Plantations could also contribute to the conservation of biodiversity by providing an 
environment not only for native woody plants, but also for the forest herb species (Boothroyd-Roberts $e t$ al. 2013).

Eucalyptus plantations indicate that they often promote the recruitment, establishment and succession of native woody species by functioning as foster ecosystems (Senbeta and Teketay 2000, Yirdaw and Luukkanen 2003). Also, it has been found that regeneration is higher in Eucalyptus plantations compared to, for example, plantations of Cupressus lusitanica and Pinus spp., a pattern attributed to more light in the Eucalyptus plantations (Yirdaw 2001, Lemenih et al. 2004).

Properly managed Eucalyptus plantations can control soil erosion, but their effect depends on such factors as intensity of rainfall, soil condition, slope angle, slope length and the presence of ground vegetation and litter cover. However, planting of any kind of tree species in the form of a monoculture should not be taken as the best solution to soil erosion, particularly sheet or surface erosion (Davidson 1989). The litter which accumulates under most Eucalyptus plantations can help to form a protective barrier against erosion, but in many places the litter is collected as fuel or removed to reduce fire hazard. If the litter is left on the site uncollected, it would have been incorporated into the soil system to slow down runoff and improve infiltration, and substantial amount of nutrients may pass to the soil system, thereby improving soil fertility.

Accessibility of seeds from the mother tree (seed collection) is simple, locally available and do not require special treatment to keep (store) for long time (Kidanu 2004). Eucalyptus as a genus is also well known for its good coppicing ability, it usually forms a dense and productive stand if allowed to re-grow (Kidanu 2004). It can grow in degraded land, swampy area, unfertile and exhausted soil, and in dry areas (Pohjonen and Pukkala 1990).

Eucalyptus, with almost 900 species, is found worldwide; More than 300 species of this genus contain volatile oils which occurred in many parts of the plant, depending on the species, but in the leaves that oils were most plentiful (Pino et al. 2002 and Getahun 2002).

There were three broad categories of uses for Eucalyptus oil (medicinal, industrial and perfumery/ flavouring). Medicinal oils were used primarily as a decongestant agent and antiseptic in inhalants, sprays, embrocations, gargles and lozenges. It was also prepared as emulsions, ointments and other preparations. Industrial oils were used in the manufacture of disinfectants, deodorants, liquid soaps, germicides and in the manufacture of synthetic menthol and thymol. Perfumery and flavouring oils were used either directly as a scenting agent and food flavouring, or in the synthesis of other scents and flavor (Pearson 1993). Eucalyptus tree has ulcer-healing promoting effect of the methanol extracts of the leaves, also an inhibitory effect on some types of inflammation and analgesic effect. It also have Antioxidant effect, Cytotoxic effect, Antiparasitic, insecticidal and repellent effects, Antimicrobial effect, effects on oral and dental health, dermatological effects and scalp lotion (Ali and Al-Snafi 2017).

Eucalyptus species are often considered less palatable to wildlife. However, several marsupial herbivores, notably koalas and some possums, eat Eucalyptus leaves. The flowers produce a great abundance of nectar, providing food for many pollinators including insects (e.g. honeybees), birds and mammals (e.g. bats, possums). It is also a habitat for certain species of wildlife. Establishing plantations in treeless areas can provide shelter for wildlife. Plantations can be made more favorable for plants and animals by the appropriate management practices that provide desired habitat. In India, planting Eucalyptus species has increased the number of animals.

In swampy areas, the groundwater level is near or at the surface, and some species of Eucalyptus have been used to drain the water away by drawing it up through the roots (Teketay 2000). E. globulus is useful for this purpose. Mosquito breeding areas can sometimes be controlled in this way. Drainage removes swamps which provide a habitat for mosquito larvae, thereby reducing the risk of malaria. This 
method has been used in Algeria, Lebanon, Europe and California. However, drainage can also destroy ecologically productive areas.

Agro forestry is an approach to land use based on integrating trees and shrubs into crop and livestock production systems. Thus, Eucalyptus species can be used in agro forestry systems, i.e. they can be planted in homesteads, farm boundaries, farm woodlots and roadsides. They provide various benefits, particularly fuel wood and construction material, and thereby make an important contribution to improved rural living. In India, farmers are planting Eucalyptus in farm boundaries. In Pakistan, intercropping with strips of E. camaldulensis increased the production of cotton under irrigation. This is because it can help to reduce salination. In Colombia, single trees of E. camaldulensis are grown in field boundaries for the pulpwood market. On the highland Vertisols of Ethiopia, E. globulus trees are planted in farm boundaries for multiple purposes such as fuelwood, timber, as a cash crop, boundary demarcation, fencing, soil and water conservation, and increasing crop yield (Kidanu 2004).

Climate change is one of the greatest challenges the world is facing today. Climate change is caused by the increase in the concentration of carbon dioxide and other greenhouse gases in the atmosphere mainly as a result of human activities. Global climate change has led to sea level rise (due to melting of ice and glaciers and expansion of sea water resulting from rising temperatures), changes in global precipitation patterns, increased frequency and intensity of extreme weather events, such as droughts and floods, shifts in the distribution of species and ecosystems, desertification and increased incidence of pests and diseases. Climate change brings complex changes in species composition and interactions, and may result in a significant reduction in biodiversity (Mooney et al. 1995). Climate change will have significant environmental, social, economic and political impacts. One of the main strategies to mitigate climate change is tree planting. Eucalyptus species are one of the best tree species since they are fast growing and can fix more $\mathrm{CO}_{2}$ by the process of photosynthesis, thereby serving as a carbon sink. Eucalyptus is an efficient biomass producer; it can produce more biomass than many other tree species. It is known that carbon sequestration is proportional to biomass production. In the Ethiopian highlands, the annual wood production rates for E. globulus range between 168 and 2,900 kg/ha/year depending on soil type, stand age and rotation cycle (Kidanu 2004), thus indicating more carbon sequestration in the biomass. On the other hand, recent studies elsewhere showed that inter planting Eucalyptus species with nitrogen-fixing species like Acacia and Albizia species can promote carbon sequestration. Therefore, Eucalyptus plantations can play an important role in mitigating climate change and generating additional revenues from carbon trade.

Eucalyptus has wide ecological range and multi-functional advantage for farmers (those living in diverse soil and climatic conditions with different needs) can plant and use eucalyptus (Hailemicael 2012). Farmers prioritize to plant eucalyptus on their pieces of land in different ways; Accessibility of seeds locally and do not require special treatment to keep (store) for long time, its coppicing ability and its fast secondary growth (Zerfu 2000), wide range adaptability in degraded land, swampy area, unfertile and exhausted soil, and in dry areas (Pohjonen and Pukkala 1990), and it does not require intensive management hence reducing the labor cost.

Because of its fast development, farmers prefer eucalyptus to solve the growing demand for wood and wood products, generate income and address the ever-increasing shortage of wood products. Eucalyptus has a social value as its widespread use create employment opportunity. Hence, smallholders in Ethiopia prefer to plant eucalyptus due to its positive influence on their livelihood, and the contribution to job opportunities for all ages and particularly for women (Hailemicael 2012). 


\section{Ecological impacts of eucalyptus plantation}

Eucalyptus is not good tree for erosion control. Under dry condition ground vegetation is suppressed by root competition. In areas, where eucalyptus tree are inter cropped with other trees, the problem is minimal and absent, whereas in areas covered with only eucalyptus woodlots there is more soil erosion and gully formation (Zerga 2015). Most eucalypts are not good trees for erosion control. When young, they are very susceptible to grass competition, and to obtain good growth clean weeding is necessary during the establishment period, which is undesirable on steep or eroding terrain. Even mature stands may be ineffective in halting surface run-off (FAO 1985).

In eucalyptus plantation area, understory development and litter build-up were insufficient to prevent surface run-off. It is a fast growing, heavy crowned tree which casts a dense shade but little litter. In closed plantations it has a great water demand and an exceptionally extensive and dense root system which enable it to compete successfully for available soil moisture, especially with smaller, shallow rooted plants (FAO 1985).

\section{Impacts of Eucalyptus Plantation on Water Resource}

The main criticisms that have been launched against Eucalyptus plantations in this respect are that they deplete water supplies and that, on sloping catchments, they do not regulate the flow of water as well as the natural vegetation which they sometimes replace (FAO 1985). The possible ecological effects of eucalypt plantations could be on the local or regional climate, the microclimate within the forest; surface run-off of water (which may affect water quality and the amount of erosion); soil moisture content and; the recharge of aquifers. Eucalyptus plantations can, in principle, affect any of these by altering the quantities. Whether these changes are considered beneficial or not depends on the purpose of the plantations and a balance of the various costs and benefits in each instance (FAO 1985).

There is limited evidence regarding the impacts of Eucalyptus on water. Certain trees that are integrated into agricultural systems can increase the efficiency of water use, while plantations of fastgrowing trees like Eucalyptus trees can exacerbate the problem of water shortages. It is claimed that Eucalyptus trees absorb more water from the soil than any other tree species. The results in Kenya shows that, Eucalyptus consumes more water, especially during its early growing stages compared to pinus species (Dye and Bosch 2000). Depletion of the water table and effects on the hydrological cycle are common against the planting of Eucalyptus. However, there have been few empirical studies that have addressed the issue of water use by the eucalypts and their direct effect on adjacent crop outputs.

According to Khan and Mahmood-Ul-Hasan (2006) study result in Pakistan, Eucalyptus plantation evaporates high ratio of the groundwater into atmosphere causing dryness of the rock reservoirs change in the flow of water from the springs and also decline in water table. Similar results were done by Tilashworki (2009) at Koga watershed of Amhara Region, Ethiopia. According to the results, Eucalyptus plantations around water sources significantly affect the flow of springs, and the disappearance of springs, evidently due to Eucalyptus plantations, and as a result, the community has banned any further plantations around water sources, such as ponds or springs.

The amount of run-off depends upon the presence of litter and ground vegetation and this will certainly vary greatly according to the climate. The little evidence that exists suggesting that run-off from eucalypt plantations is greater than from grass land or low shrub vegetation. The ground vegetation of eucalypt forests is sparse in dry climates due to root competition and, perhaps, allelopathic effects (FAO 1985).

There is a misconception by most people that eucalyptus consumes a lot of water more than any other tree species and agricultural crop. And they were come up with results show that eucalyptus is efficient water user. Davidson (1989) reveals that for the same amount of water consumed eucalyptus 
produce higher amount of biomass which is economically profitable and acceptable. Most eucalyptus species need on average 785 liters of water $/ \mathrm{kg}$ of biomass produced as opposed to cotton/coffee/banana (3200), sunflower (2400), field pea (2000), cow pea (1667) soybeans (1430), potato (1000), sorghum (1000) and maize (1000) liters/kg biomass produced, which shows that eucalyptus species are efficient water users. In contrast the cutting of extensive eucalyptus forests can increase the water yield of a Catchment considerably and raise water tables in flat land downstream. Their high water requirements and deep root systems can give them a relative advantage over other plants in terms of water usage, which can be particularly damaging if Eucalyptus trees are planted in arid regions (Janger and Pender 2003).

The plantation of extensive forests of eucalypt in any deforested catchment will substantially decreases water yield from that catchment; the felling of such forests will increase it. The effect of eucalypts in reducing water yield is probably greater than that of other broad-leaved species, but all species of trees reduce water yield compared with scrub or grass. The effects of eucalypts on run-off, and therefore on erosion, vary greatly according to local conditions of climate, slope, and use of the ground vegetation and litter by local peoples (FAO 1985).

\section{Effects on Climate}

One of the criticisms against Eucalyptus plantations is that they may cause a change in the local climate. This is because of their very high evapo-transpiration rate, which may lead to a lower water table. This high rate of soil water loss is claimed adversely to affect local rainfall levels, resulting in possible desertification of the area. In terms of their effects on regional rainfall or on other regional climatic parameters, however, there is nothing to distinguish eucalypts from plantations of any other tree or from different types of native forests of similar structure and albedo (FAO 2011).

The effects of the eucalypts on micro-climate at local level are very well recognized. They include lowering of temperature, $\mathrm{CO}_{2}$ fixation, shading etc. In Senegal, for example, microclimate changes occurred when Eucalyptus plantations were established in Acacia forest sites (Bernhard-Reversat 1988). But the extent of these effects depends on the amount of leaf surface carried by the trees in relation to the surface area of the ground covered. In the shaded area, average air temperatures are lower, extremes of air and surface soil temperatures are reduced and there is a higher surface air humidity compared to areas with no trees. Generally, the greater the leaf area and the more horizontal the leaves are, the greater the shading effect and the higher the evapo-transpiration rate. Eucalypts cast less shade, on average, than other broadleaved trees, but there are big differences in the amount of shade cast by different species because they have different leaf sizes and orientations (FAO 2011).

\section{Impacts of Eucalyptus on Soil nutrients}

The effects of Eucalyptus on soil have been noted as it sucks up soil nutrient exhaustion others un specified effects, the tree uses a lot of nutrient which is leading to soil exhaustion and reduction of crop yields. The criticisms on Eucalyptus are argued only on some species, mainly the deep rooted types, that drain water resources, and that poor forestry practices, like high planting densities and short crop rotations, are primarily responsible for depletion of the soil's nutrients, increased soil erosion, and suppression of the undergrowth (Dessie and Erkossa 2011).

Fast growing and short rotation tree plantations, such as Eucalyptus also use huge amounts of nutrients from the soil in comparison to slow-growing species (Dessie and Erkossa 2011). Monoculture forest activities, such as Eucalyptus plantations may further affect soil chemical characteristics if the organic litter is continuously raked, prohibiting nutrient recycling (Zewdie 2008). 
According to FAO (2011) there is an increase in soil bulk density in Brazil, Botswana and Australia with regard to the native forest, associated with reduced soil infiltration, increased surface run off, with consequent reduction in soil moisture. Rhoades and Binkley (1996) and Cao et al. (2010) pointed out that there is a reduction in soil pH. FAO (2011) and Tererai et al. (2014) found that soil total $\mathrm{N}$ decreased with an increase in Eucalyptus camaldulensis cover compared to the site not covered by the Eucalyptus spp.

The potential negative impacts of Eucalyptus plantations on soil quality and other ecosystem services have been intensively studied. Across many tropical and sub-tropical regions, there is high demand for soil nutrients as an important drawback to Eucalyptus plantations (Kidanu et al. 2005). According to FAO (2009) reports, improper land use and soil management, which often leave the soil with less or no vegetation, are often the major causes of soil quality deterioration. However, fast growing tree plantations may also lead to soil quality decline when they are poorly planned and not properly managed. The impact of tree plantations upon soil resources has been very much debated and there is no complete consolidated view, partly due to the fact that the impact is much dependent on variable site and forest conditions (Janger and Pender 2000).

According to some authorities, monoculture plantation forestry may affect soil chemical properties in two ways: nutrient depletion from the soil into the tree components, and change in the chemical status of the soil surface as the litter layer is dominated by leaf fall derived from one species. Forest management practices can aggravate or reduce the magnitude of these effects. Species vary widely in their inherent nutrient requirements and use. Most of the environmental concerns about short rotation forestry management, such as that of Eucalyptus revolve around nutrient removal following harvest. There is significant support in the literature for the assertion that all fast growing tree crops, such as Eucalyptus are associated with a more intense uptake of nutrients from the soil, compared to slow growing forests and hence they deplete the nutrients on a site (FAO 2011).

Nutrients are exported out from the plantation's soil system by removing trees from timber sales and fuel wood (Zerfu 2000). From the soil nutrients, total nitrogen percentage in the plow zone from 0 to 20 $\mathrm{cm}$ depth at all distances were in the very high range. Near the Eucalyptus stand, this might be due to its allelopathic effect, which opposes the mineral up take by the plants and low mineralization (Tilashworki 2009). Whole-tree harvesting coupled with short harvest cycles may result in greater soil nutrient depletion than conventional forest harvesting. Consequently, when Eucalyptus is grown as a short rotation crop for high biomass production, soil nutrients are depleted rapidly. The reduction in nutrient content of the soil under such conditions may be explained by the nutrient drain through harvest removals.

\section{Allelopathic effect on agricultural crops}

Allelopathy is defined as direct and indirect effects of allelochemical compound resulted from organism which may have inhibitor or stimulator effects on the same or different organism. In this process, synthesis of biologically active molecules produced by plant and their residue may convert to other forms and influenced on the growth of similar or non-similar plants (Saberi et al. 2013). Allelopathic compounds restrict plant growth through negative interactions with important physiological processes such as changes in cell wall structure, prevention of cell division and activity of some enzymes. These compounds can also affect the equilibrium of plant hormones, pollen tube germination, absorption of nutrient elements, displacement of stomata, photosynthesis, respiration, protein synthesis, pigment, and changes in DNA and RNA structures (Saberi et al. 2013).

There have been suggestions that certain species of Eucalyptus may produce chemicals from their leaves or litter that inhibit the germination or growth of other species of plant. There has been the same 
experimental work which shows that some species of eucalypt do have an inhibitory effect on the associated vegetation (FAO 1985). According to FAO (1985), Eucalyptus camaldulensis inhibited improved grassland species. There was more vegetation under oak, in $45 \%$ sunlight, than under the eucalypt, in 64\% sunlight; soil moisture in the litter zone was greater than in open areas nearby. There is a scarcity of herbaceous plants in the plantations of Eucalyptus in Central Iraq, which was not due to moisture, nutrients or shading; but-leaf extracts, decaying leaves and soil inhibited germination and growth of associated species. The volatile inhibitors found were the same as those identified for eucalyptus globulus by Del Moral and Muller (1969). They found that the absence of vegetation beneath eucalyptus globulus could not be attributed to competition for essential resources, but on phytotoxins in fog-drip appeared to be capable of causing this. According to Saberi et al. (2013) results indicated that aerial and underground extracts of Eucalyptus camaldulensis could effect germination and early seedling growth of sample trees.

There are some researches which can be concluded that various solvent extracts of leaves of Eucalyptus globulus had allelopathic effects on germination and seedling growth of eggplant cv. Black Beauty. The extracts reduced germination and growth of seedlings and this inhibitory effect increased with increasing extract concentration (Dejam et al. 2014) and Similar results were obtained in tomato by (Fikreyesus et al. 2011 ), in wheat by (Khan et al. 2008) and in cucumber by (Allolli and Narayanareddy 2000).

\section{Social aspects of eucalyptus}

In many countries in Latin America, Africa, and the Indian subcontinent, severe ecological degradation has taken place due to the uncontrolled clearance of vegetation both for agriculture and for use of wood as fuel. The traditional trees, which sustained the health, agricultural practices and rural economy, have ended up as firewood. Floods and physiological droughts are the consequences of this denudation. In many regions of the world, fuel wood, and not agricultural produce, is today the priority. The biomass part of the total energy consumption is $1 \%$ in developed countries and $39-43 \%$ in developing countries. If this were to be met from sustainable sources, fruit and fodder trees would reclose the countryside. Cattle dung and agricultural waste, presently used as fuel, could instead benefit the agriculture fields. When large scale cultivation was taken up in lands earlier under agriculture, several distortions resulted locally, such as a fall in the production of agricultural produce and a rise in unemployment. These issues have resulted in controversies (FAO 2007).

Firewood has always been regarded as a free good by the rural poor in developing countries. It is freely gathered from government forests and communal lands. As long as commercial sale of wood did not occur, such removals from communal areas were accepted by the community. With the conversion of the sites into plantations, restrictions come into force. Eucalypt plantations raised on communal land are reported to have caused problems of this type in some regions. This could occur with any development programme covering denuded communal lands and the solution lies in safe-guarding the interests of the poor, by regulating the conversion and building in components to benefit them. Once the plantation is established, leaf fall could serve to meet the some biomass needs - a social benefit, which however may be opposed to silvicultural needs (FAO 2007 and FAO 2002).

Eucalyptus plantation becomes increasing from time to time which results a dwindling in the food production and amount of productive land, between 1981 and 1988, 8.6 billion trees were planted by farmers in India. Eucalypts constituted $85 \%$ of these. Planting was undertaken both on uncultivated land, privately owned, marginal land and on agricultural lands and half of the area was found to have been under rained agriculture prior to the planting. 
Employment opportunity is the main thing in the economy of a country according to some authors eucalyptus can reduce the number of employment opportunity, with the direct effect on the well-being of the community. Rain fed agricultural in the tropics require 150-180 man days of labor per year, but the requirement of labor for raising and tending of an Eucalyptus plantation would be 350-400 man days in the establishment and about 40 man days per year thereafter. Tree felling and debarking are done by skilled labor moving from site to site, rather than by local people. Thus, if eucalypt planting is taken up only in erstwhile agricultural areas, it results in loss of employment (Deshpande and Chandrashekar 1984). It has been contended that the economic benefits accruing to landowners in the rural areas through cultivation of eucalypts has widened the gap between the rich and the poor, disrupting the social fabric. The rich have become richer.

Eucalyptus was the most dominant genus that will be used in plantation and woodlot forestry, with different controversies. The introduction was due to the scarcity of fuel wood and their easy adaptation of the crop in any climatic and soil character. It is usually the tree of alternatives for smallholder, because plantation can be established cheaply, it can be cultivated easily, it has reliable markets and the products earn good prices all of which continue to encourage the expansion of the tree and make it one of the most widely planted exotic trees in the region.

There are so many importance of the tree regarding social value, alternatives for fuel wood and minimization of the clearance of native forest for fuel wood. But there is also some impact on the community and the biodiversity which facilitate biodiversity loss, secretion of allelochimicals with a direct effect on the adjacent crop, The other criticisms on Eucalyptus was mainly on the deep rooted types, that drain water resources and short crop rotations, are primarily responsible for depletion of the soil's nutrients, increased soil erosion, and suppression of the undergrowth and also depletes ground water resources. Social and economic problems arising from insensitive plantation establishment or unwise management are real, in most developing countries in the tropics, ecological degradation - due to clearance of trees for agriculture on marginal lands and for meeting firewood needs- contribute to environmental degradation. It also has a positive impact on bio diversity conservation and fostering of native vegetation, control soil erosion, but monoculture plantation is the last alternative, pharmacological importance by containing volatile oils and source of antioxidant effect, it serves as a food and habitat for wildlife especially birds and draining of swampy areas.

Eucalypts are neither good nor bad, and therefore a careful analysis of the ecological and social implications should be undertaken before planting. Growing a crop is a matter of choice. The costs and benefits of planting fast-growing trees including Eucalyptus need careful assessment based on detailed site studies with due consideration to both environmental and socio-economic needs. Decisions such as what, where, why and how to grow and how to manage it have to be made, and the social and ecological implications of each decision, as well as the economic implications, have to be weighted up. Some of the perceived problems with eucalypts can be avoided by applying sensible management practices. If the adverse effects of the trees are intolerably great, then other crops should be considered.

\section{REFERENCES}

Abebe, M. and W. Tadesse. 2003. Eucalyptus in Ethiopia: Risk or Opportunity? Ethiopian Institute of Agricultural Research, Addis Ababa, Ethiopia. 65 pp.

Ali, E. and Al-Snafi. 2017. The pharmacological and therapeutic importance of Eucalyptus species grown in Iraq. IOSR J. Pharmacy. 7(3): 72-91.

Allolli, T. B. and P. Narayanareddy. 2000. Allelopathic effect of eucalyptus plant extract on germination and seedling growth of cucumber. Kamataka J. Agric. Sci. 13(4): 947-951. 
Bernhard-Reversat, F. 1988. Soil nitrogen mineralization under a Eucalyptus plantation and a natural Acacia forest in Senegal. For. Ecol. Manage. 23: 233-244.

Boothroyd-Roberts, K., D. Gagnon and B. Truax. 2013. Hybrid poplar plantations are suitable habitat for reintroduced forest herbs with conservation. Spring Open J. 2:1-13.

Cao, Y., S. Fu, X. Zou, H. Cao, Y. Shao and L. Zhou. 2010. Soil microbial community composition under Eucalyptus plantations of different age in subtropical China. European J. Soil Biol. 46(2): 128-135.

Davidson, J. 1989. The eucalypt dilemma: argument for and against eucalypt planting in Ethiopia. The forestry research center, Addis Ababa. African Sun Publishing, Oakland.

Dejam, M., S. S. Khaleghi and R. Ataollahi. 2014. Allelopathic effects of Eucalyptus globulus Labill. on seed germination and seedling growth of eggplant (Solanum melongena L.). Intl. J. Farm. Alli. Sci. 3(1): 81-86.

Del Moral, R. and C. H. Muller. 1969. Fog-drip: a mechanism of toxin transport from Eucalyptus globulus. Bull. 'Iorrey Bot. Club. 96(4): 467-475.

Deshpande, R. S. and H. Chandrashekar. 1984. Is eucalypts farming really uneconomic? Workshop on Eucalyptus Plantation, Indian Statistical Institute, Bangalore. India.

Dessie, G. and T. Erkossa. 2011. Eucalyptus in East Africa: Socio-economic and environmental issues. FAO. 30 pp.

Dye, P. J. and J. M. Bosch. 2000. Sustained water yield in afforested catchments-the South African experience. In: K. von Gadow, T. Pukkala and M. Tome (eds). Sustainable forest management. Kluwer academic publishers, Dordrecht., pp. 99-120.

FAO. 1979. Eucalyptus for planting. FAO forestry and forest products study No.11. FAO, Rome.

FAO. 1985. The ecological effects of eucalyptus. FAO forestry paper. FAO, Rome.

FAO. 2002. Annotated bibliography on environmental, social and economic impacts of Eucalypts. Forest Plantations Working Papers, Forest Resources Development Service, Forest Resources Division. FAO, Rome.

FAO. 2007. The ecological, economic and social effects of eucalyptus FAO corporate document repository. Regional office for Asia and the pacific.

FAO. 2009. Eucalyptus in East Africa: The Socio-economic and Environmental Issues. Addis Ababa.

FAO. 2011. Eucalyptus in East Africa: Socio-economic and environmental issues. Planted Forests and Trees Working Paper, Forest Management Team, Forest Management Division. FAO, Rome.

Fikreyesus, S., Z. Kebebew, A. Nebiyu, N. Zeleke and S. Bogale. 2011. Allelopathic Effects of Eucalyptus camaldulensis Dehnh. On germination and growth of tomato. American-Eurasian $J$. Agric. Environ. Sci. 11(5): 600-608.

Friis, I. 1995. Myrtaceae. In: S. Edward, M. Tadesse and I. Hedberg (eds.). Flora of Ethiopia and Eritrea: Canellaceae to Euphorbiaceae. The National Herbarium, Addis Ababa University and Department of Systematic Botany, Uppsala University, Uppsala., pp.71-106. 
Getahun, A. 2002. Eucalyptus Farming in Ethiopia: The Case for Eucalyptus Woodlots in the Amhara Region. Bahir Dar Conference Proceedings, Ethiopian Society of Soil Science, Bahir Dar., pp. 137153.

Gil, L., W. Tadesse, E. Tolosana and R. Lopez (eds.). 2010. Eucalyptus Species Management, History, Status and Trends in Ethiopia. Proceedings from the Congress, Addis Ababa.

Hailemicael, B. K. 2012. The Contribution of Eucalyptus Woodlots to the Livelihoods of Small Scale Farmers in Tropical and Subtropical Countries with Special Reference to the Ethiopian Highlands. Master Thesis. Swedish University of Agricultural Sciences. 43 pp.

Janger, P. and J. Pender. 2000. The role of trees for sustainable management of less-favored lands: the case of Eucalyptus in Ethiopia. Forest Policy and Economics. 5(1): 83-95.

Janger, P. and J. Pender. 2003. The role of trees for sustainable Management of less favoured lands: the case of Eucalyptus in Ethiopia. Forest Policy economics. 5: 83-95.

Kenya forest service. 2009. A Guide to On-Farm Eucalyptus Growing in Kenya

Khan, A. M., I. Hussain and A. E. Khan. 2008. Allelopathic effects of eucalyptus (Eucalyptus camaldulensis L.) on germination and seedling growth of wheat (Triticum aestivum L). Pak. J. Weed Sci. Res. 15(2-3): 131-143.

Khan, S. and Mahmood-Ul-Hasan. 2006. Impact of eucalyptus on the underground water in Pakistan. USPAM Conference, Vietnam.

Khan, S. and U. H. Mohmood. 2010. Impacts of Eucalyptus on the Underground Water (A case study of Udigram Swat Valley Northwest Pakistan). Ohrid, Republic of Macedonia: BALWOIS.

Kidanu, S. 2004. Using Eucalyptus for soil and water conservation in the Highland Vertisols of Ethiopia. Ph. D. Thesis. Wageningen University, Wageningen, Netherlands. 198 pp.

Kidanu, S., T. Mamo and L. Stroosnijder. 2005. Biomass production of Eucalyptus boundary plantations and their effect on crop productivity on Ethiopian highland Vertisols. Agroforestry Forum. 63: 281290.

Lemenih, M. 2010. Growing Eucalyptus by smallholder farmers in Ethiopia. In: L. Gil, T. Wubalem, E. Tolosana and R. Lopez. (eds.). Eucalyptus Species Management, History, Status and Trends in Ethiopia. Ethiopian Institute of Agricultural Research, Addis Ababa, Ethiopia., pp. 91-103.

Lemenih, M. and D. Teketay. 2005. Effect of Prior land use on the recolonization of native woody species under plantation forests in the highlands of Ethiopia. For. Ecol. Manag. 218: 60-73.

Lemenih, M., T. Gidyelew and D. Teketay. 2004. Effects of canopy cover and under-canopy microclimate factors of tree plantations on the composition, density and growth of native woody species in the southern highlands of Ethiopia. For. Ecol. Manag. 194: 1-10.

Mooney, H. A., J. Lubchenco, R. Dirzo and O. E. Sala. 1995. Biodiversity and ecosystem functioning: Ecosystem analyses. In: V. H. Heywood (ed.). Global biodiversity assessment. UNEP, Cambridge University Press, Cambridge., pp. 327-352.

Muluneh, M. 2011. Eucalyptus plantations in the highlands of Ethiopia revisited: A comparison of soil nutrient status after the first coppicing. Master Thesis. Mountain Forestry program, University of Natural Resources and Life Sciences Vienna, Austria. 
Pearson, M. 1993. The good oil: Eucalyptus oil distilleries in Australia. Australian Historical Archaeology. 11: 99-107.

Pino, J. A., R. Marbot, R. Quert and H. Garcia. 2002. Study of essential oils of Eucalyptus resinifera, E. tereticornis and Corymbia maculata (Hook.) grown in Cuba. Flavour Frag. J. 17: 1-14.

Pohjonen, V. and T. Pukkala. 1990. Eucalyptus globules in Ethiopia forestry. For. Ecol. Manag. 36: 1931.

Rhoades, C., and D. Binkley. 1996. Factors Influencing Decline in Soil pH in Hawaiian Eucalyptus and Albizia plantations. For. Ecol. Manag. 8: 47-56.

Saberi, M., A. Davari , F. Tarnian, M. Shahreki and E. Shahreki. 2013. Allelopathic Effects of Eucalyptus camaldulensis on Seed Germination and Initial Growth of four range species. Annals of Biol. Res. 4(1): 152-159.

Senbeta, F. and D. Teketay. 2000. Regeneration of indigenous woody species under the canopies of tree plantations in Central Ethiopia. Trop. Ecol. 42:175-185.

Senbeta, F., D. Teketay, and A. B. Naslund. 2002. Native woody species regeneration in exotic tree plantations at Munessa-Shashemene Forest, southern Ethiopia. N. Fores. 24: 131-145.

Teketay, D. 2000. Facts and experience on eucalyptus in Ethiopia and elsewhere: ground for making wise and informed decision. Workshop on Eucalyptus Dilemma.

Tererai, F., M. Gaertner, S. M. Jacobs and D. M. Richardson. 2014. Eucalyptus Camaldulensis Invasion in Riparian Zones reveals few Significant Effects on Soil Physico-Chemical Properties. River Res. Appl. 7(4): 1-12.

Tilashworki, A. 2009. The Effect of Eucalyptus on Crop Productivity, and Soil Properties in the Koga Watershed, Western Amhara Region, Ethiopia. M.Sc. thesis. Cornell University, New York.

Turnbull, J. W. 1999. Eucalyptus plantations. N. Fores. 17: 37-52.

Yirdaw, E. 2001. Diversity of naturally-regenerated native woody species in forest plantations in the Ethiopian highlands. N. Fores. 22: 159-177.

Yirdaw, E. and O. Luukkanen. 2003. Indegenous woody species diversity in Eucalyptus globules (Labill.) plantations in the Ethiopian highlands. Biod. Conserv. 23: 567-582.

Zerfu, H. 2000. Ecological impact evaluation of Eucalyptus plantation in comparison with agricultural and grazing land-use types in the highlands of Ethiopia. Ph. D. Thesis. Institute of Forest Ecology, Vienna University of Agricultural Science, Vienna.

Zerga, B. 2015. Ecological impacts of Eucalyptus plantation in Eza Wereda, Ethiopia. Int. Inv. J. Agric. Soil Sci. 3(4): 47-51.

Zewdie, M. 2008. Temporal changes of biomass production, soil properties, and ground flora in Eucalyptus globulus plantations in the central highlands of Ethiopia. Ph.D. Thesis. Uppsala, Swedish University of Agricultural Sciences. 